\title{
A Comparison of Real-Time PCR Protocols for the Quantitative Monitoring of Asymptomatic Olive Infections by Verticillium dahliae Pathotypes
}

\author{
D. Gramaje, V. Pérez-Serrano, M. Montes-Borrego, J. A. Navas-Cortés, R. M. Jiménez-Díaz, and B. B. Landa
}

Department of Crop Protection, Institute for Sustainable Agriculture (IAS), Spanish National Research Council (CSIC), Campus de Excelencia Internacional Agroalimentario, ceiA3, Avda. Alameda del Obispo s/n, P.O. Box 4084, 14080, Cordoba, Spain. Accepted for publication 25 March 2013.

\begin{abstract}
Gramaje, D., Pérez-Serrano, V., Montes-Borrego, M., Navas-Cortés, J. A., Jiménez-Díaz, R. M., and Landa, B. B. 2013. A comparison of real-time PCR protocols for the quantitative monitoring of asymptomatic olive infections by Verticillium dahliae pathotypes. Phytopathology 103:10581068 .

Early, specific, and accurate in planta detection and quantification of Verticillium dahliae are essential to prevent the spread of Verticillium wilt in olive using certified pathogen-free planting material and development of resistance. We comparatively assessed the accuracy, specificity, and efficiency of eight real-time quantitative polymerase chain reaction protocols published since 2002 for the specific detection and quantification of $V$. dahliae in various host plant species and in soil, using a background of DNAs extracted from olive roots, stems, and leaves. Results showed that some of those protocols were not specific for $V$. dahliae or were inhibited when using backgrounds other than water. Ranking of protocols according to a weighted score system placed proto-

different types of olive tissues (root and stem) tested. Use of TAQ and SYBR-4 protocols allowed accurate quantification of $V$. dahliae DNA regardless of the background DNA, with a detection limit being fixed at a cycle threshold of $36(\approx 18 \mathrm{fg}$ for SYBR-4 and $15 \mathrm{fg}$ for TAQ) of $V$. dahliae. The amount of DNA from defoliating (D) and nondefoliating (ND) V. dahliae pathotypes was monitored in Verticillium wilt-resistant 'Frantoio' olive using the TAQ and SYBR-4 protocols. In the infection bioassay, higher amounts of D V. dahliae DNA were measured in olive stems, whereas the average amount of fungal DNA in roots was higher for ND-infected plants than D-infected ones. Overall, $V$. dahliae DNA amounts in all olive tissues tested tended to slightly decrease or remain stable by the end of the experiment (35 days after inoculation). The SYBR-4 and TAQ protocols further enabled detection of $V$. dahliae in tissues of symptomless plants, suggesting that both techniques can be useful for implementing certification schemes of pathogen-free planting material as well as helpful tools in breeding resistance to $V$. dahliae in olive.
\end{abstract} cols TAQ (based on intergenic spacer ribosomal DNA target gene) and SYBR-4 (based on the $\beta$-tubulin 2 target gene) first in sensitivity and efficiency for the quantification of $V$. dahliae DNA in small amounts and
Additional keyword: Olea europaea, olive resistance breeding, tolerance, vascular infection.
Verticillium wilt, caused by Verticillium dahliae Kleb., is currently considered the main soilborne disease threatening olive production worldwide (24). Severity of attack by this disease depends on the pathotype infecting the olive trees (41). Isolates of the defoliating (D) pathotype are highly virulent on olive compared with those of the nondefoliating (ND) pathotype. Infections by the $\mathrm{D}$ pathotype can be lethal to the plant, whereas NDinfected olive trees can eventually show symptom remission $(12,24,34,37)$.

Effective management of Verticillium wilt of olive requires the implementation of an integrated disease management (IDM) strategy that combines preplanting and postplanting control measures to promote recovery from the disease and to reduce the risk of pathogen spread to new trees $(24,41,51)$. Use of $V$. dahliaefree olive planting material for the establishment of new olive orchards in pathogen-free soils is a key component of that IDM strategy $(24,34)$. Therefore, early and accurate in planta detection and quantification of $V$. dahliae pathotypes, particularly the $\mathrm{D}$ pathotype, that ensure healthy propagation of planting material

Corresponding author: B. B. Landa; E-mail address: blanca.landa@csic.es

* The $\boldsymbol{e}$-Xtra logo stands for "electronic extra" and indicates that the online version contains two supplemental figures.

http://dx.doi.org/10.1094/PHYTO-11-12-0312-R

(C) 2013 The American Phytopathological Society are essential to prevent pathogen-infected olive trees from being planted and, thus, to facilitate the management of Verticillium wilt in olive $(24,34,50)$. Accurate in planta quantification of the pathogen biomass would also facilitate the proper characterization of resistance or tolerance to $V$. dahliae in commercial olive varieties, olive germplasm $(24,37)$, as well as in selection of wild olive genotypes potentially used as rootstocks, which has shown promise as an IDM strategy for Verticillium wilt in olive $(9,24)$.

Over the last few years, several real-time quantitative polymerase chain reaction (qPCR) protocols have been developed for the specific detection and quantification of $V$. dahliae in different host plant species and in soil (Table 1). These protocols were each evaluated and optimized for individual pathosystems in compatible interactions; however, no comparisons of the protocols on effectiveness for the quantification of $V$. dahliae in asymptomatic plant tissues or resistant or tolerant reactions have yet been made. Furthermore, some of the protocols were developed specifically for soil samples, and their efficacy has not been evaluated on plant tissues. The accuracy and reliability of the detection and quantification protocols are essential for their use in the certification of $V$. dahliae-free planting material. Consequently, in this study, we present a comparative evaluation of the protocols referred to above together with a new SYBR-Green-based protocol (named SYBR-1) developed in this study using primers previously designed by Nigro (42) but without the "scorpion" chemistry. The main objective of this research was to compare the 
weaknesses and strengths of each of the protocols and to assess their usefulness for monitoring the amount of pathogen DNA in time-course infection bioassays.

\section{MATERIALS AND METHODS}

Comparison of real-time protocols for the quantification of V. dahliae. Fungal isolates. In total, 77 fungal isolates representative of nine Verticillium spp., including V. albo-atrum (2 isolates), $V$. alfalfae (2 isolates), $V$. dahliae (49 isolates), $V$. isacii (1 isolate), V. longisporum (4 isolates), V. nonalfalfae (7 isolates), V. nubilum (1 isolate), V. tricorpus (2 isolates), and Gibellulopsis nigrescens (syn. V. nigrescens) (9 isolates) were used in this study. The $49 \mathrm{~V}$. dahliae isolates represented a wide diversity in geographic origin, vegetative compatibility grouping, and D and ND pathotypes on cotton and olive (Table 2). Those isolates were stored on plum lactose yeast extract agar (PLYA) (49) covered with liquid paraffin at $4^{\circ} \mathrm{C}$ in the dark (5). Single-spore cultures of all $V$. dahliae isolates are deposited in the culture collection of the Department of Crop Protection, Institute for Sustainable Agriculture, Spanish National Research Council, Córdoba, Spain. Active cultures of the isolates were obtained on water agar amended with chlorotetracycline (0.3 g/liter) (CWA) and subsequent subculturing on potato dextrose agar (PDA) (250 $\mathrm{g}$ of unpeeled potato,
$20 \mathrm{~g}$ of agar, and $20 \mathrm{~g}$ of glucose per liter of distilled water) or, alternatively, PLYA.

For fungal DNA extraction, actively growing cultures were placed onto a film of sterile cellophane layered over a plate of PDA and incubated for 5 to 7 days at $25^{\circ} \mathrm{C}$ in the dark. Then, mycelia growing over the cellophane surface were scraped directly with a sterile scalpel, lyophilized, and stored at $-20^{\circ} \mathrm{C}$ until used.

Plant tissue samples. To compare the different real-time qPCR assays, samples of roots, stems, and leaves were obtained from certified olive rooted cuttings of 'Frantoio' grown in sterile sand in pots inside a walk-in growth chamber (Euroclima, Córdoba, Spain) adjusted to $23 \pm 1^{\circ} \mathrm{C}$ in light and darkness, 40 to $70 \%$ relative humidity, and a 14-h photoperiod of fluorescent light of $360 \mu \mathrm{E} \mathrm{m}^{-2} \mathrm{~s}^{-1}$. After 40 days, root, stem, and leaf samples were removed from plants, washed under running tap water, and surface-disinfested in $0.5 \% \mathrm{NaClO}$ for $1.5 \mathrm{~min}$, lyophilized, ground and stored at $-20^{\circ} \mathrm{C}$ until use.

DNA extraction and quantification. Fungal and plant DNAs were extracted from $50 \mathrm{mg}$ of lyophilized plant tissue or fungal mycelium using the G-Spin IIp Plant Genomic DNA extraction kit (Intron Biotechnology, Korea) and the Fast Prep System Bio 101 (Qbiogene, Illkirch, France) according to Landa et al. (30).

DNA quality was assessed by gel electrophoresis and staining with ethidium bromide. DNA samples were quantified using the

TABLE 1. Real-time quantitative polymerase chain reaction protocols compared in this study for the efficacy in estimating Verticillium dahliae DNA in asymptomatic olive tissues, with detailed information on their properties

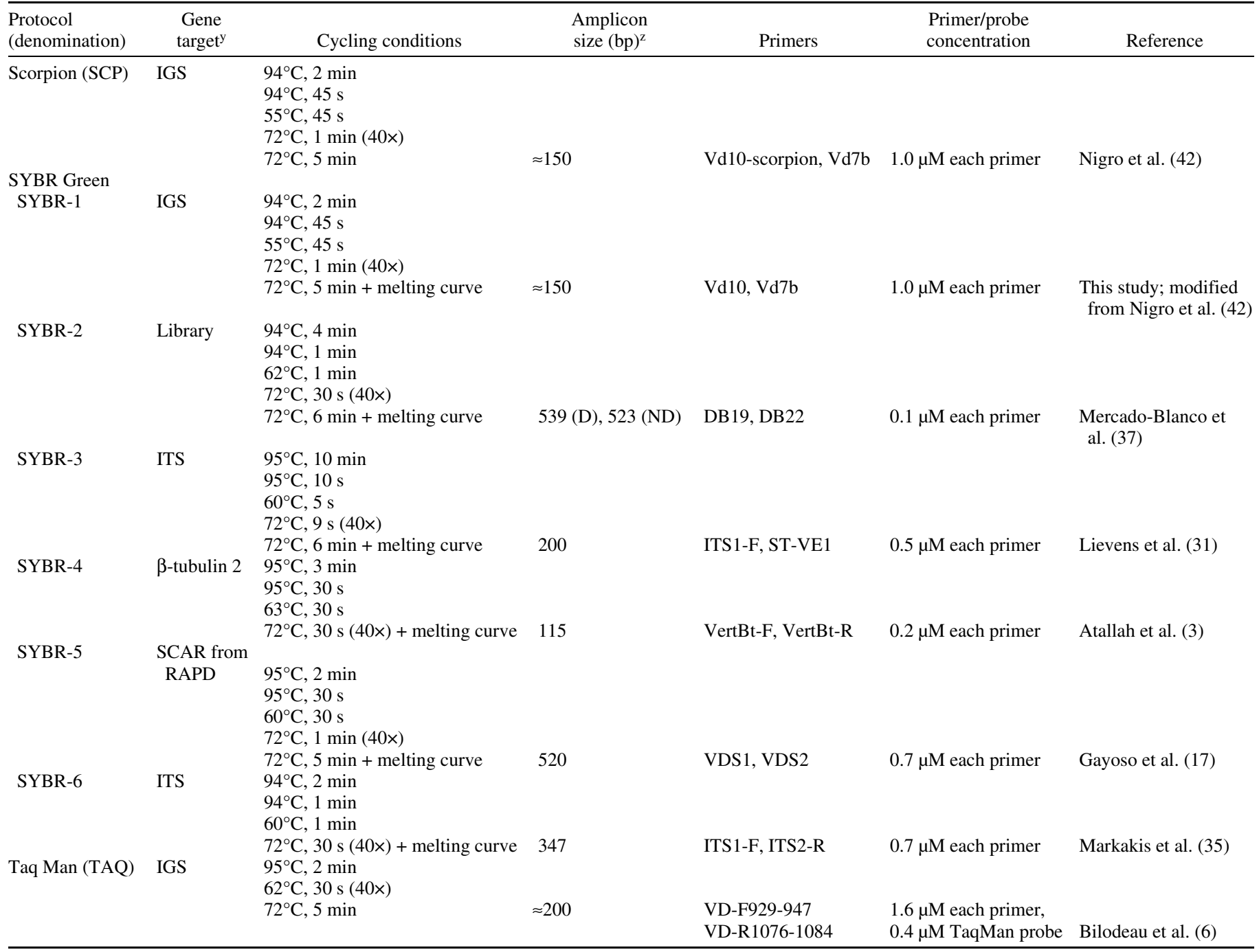

y IGS $=$ intergenic spacer, Library $=$ repetitive cloned sequence from $V$. dahliae library (Carder et al. [7]), ITS $=$ internal transcribed spacer, SCAR $=$ sequence characterized amplified region, and RAPD = random amplified polymorphic DNA.

${ }^{\mathrm{z}} \mathrm{D}$ and $\mathrm{ND}=$ defoliating and nondefoliating, respectively. 
type) or isolate V152I (ND pathotype) was added to each reaction mixture, and the total volume was $20 \mu \mathrm{l}$ in all assays. All real-time PCR assays were performed in an iCycler iQ3 (Bio-Rad) apparatus and results were analyzed with the manufacturer's software (Optical System Software v 3.0a). Assay details are outlined in Table 3 (cycling conditions, primer and probe concentrations, and so on).

DNA templates for comparisons were prepared in the same IQ 96-well microtiter plate (Bio-Rad). qPCR amplifications of each series of DNA standard curves included four replications per treatment and plate. All experiments were repeated twice independently (different PCR plates, operators, and DNA standard curves) and each included a common DNA standard curve to estimate the variability between and within experiments.

Olive- $V$. dahliae time-course of infection bioassay. Fungal isolates and plant material. V. dahliae isolates V781I (D pathotype) and V152I (ND pathotype) were used (Table 1). Plant material consisted of certified, 8-month-old rooted cuttings of Frantoio olive. Plants were kindly provided by Cotevisa (L'Alcudia, Valencia, Spain). Plants of this cultivar were obtained routinely by micropropagation techniques and exhibit resistance to Verticillium wilt when challenged with the $\mathrm{D}$ or the ND $V$. dahliae pathotypes $(14,32,33,36)$.

Olive-V. dahliae bioassay. In total, 135 plants were used in the infection bioassay that included three treatments: (i) noninoculated control (45 plants), (ii) inoculation with isolate V781I (45 plants), and (iii) inoculation with isolate V152I (45 plants). From each treatment, 30 plants were used for isolation and in planta quantification of D and ND $V$. dahliae in a time-course sampling schedule after inoculation (3 plants each per 10 sampling times between 0 and 35 days after inoculation). The remaining 15 plants of each treatment were kept as a reference for the assessment of disease symptoms.

TABLE 2. (continued from preceding page)

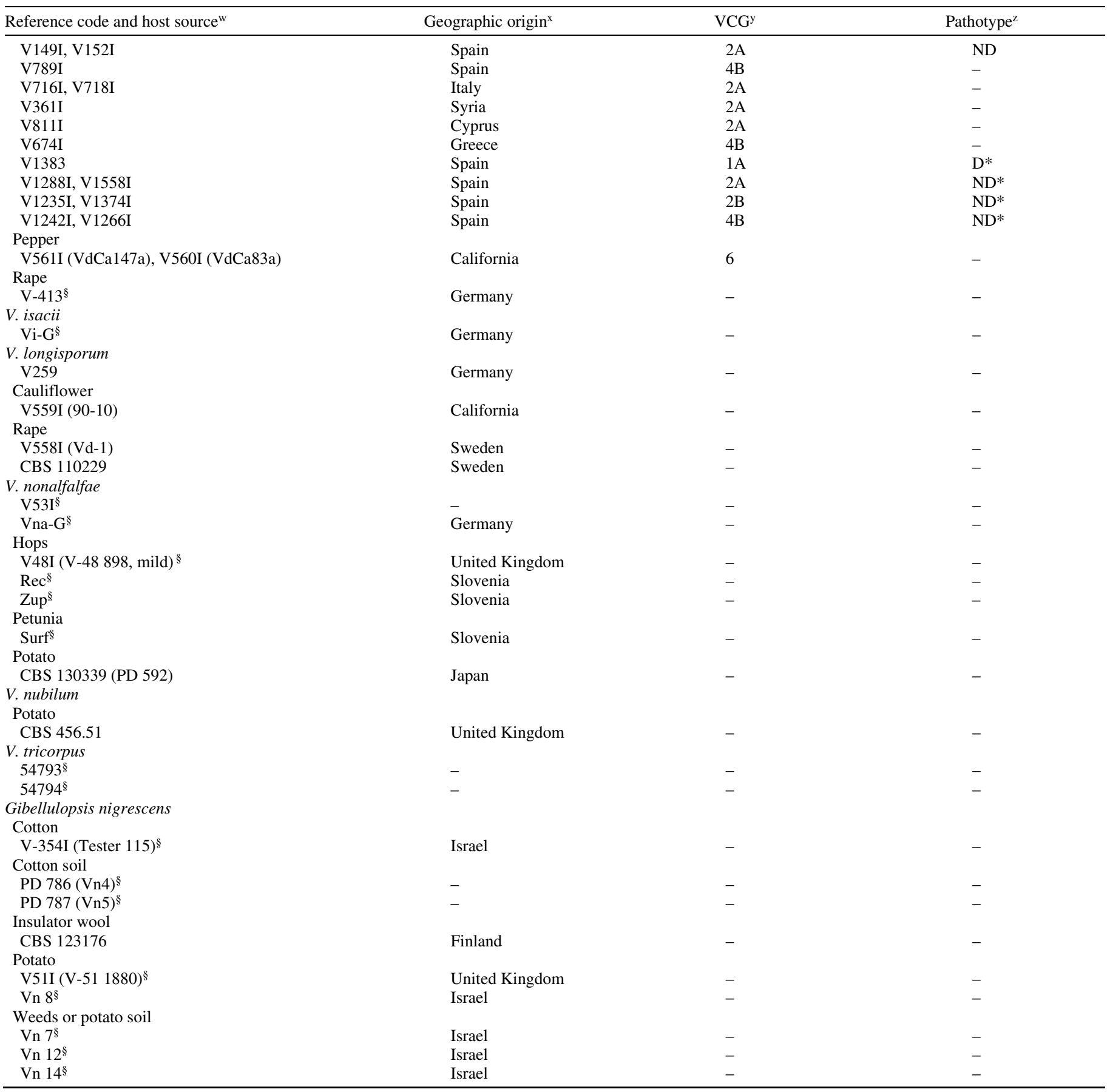


Plants were root-dip inoculated in a suspension of $10^{7}$ conidia $\mathrm{ml}^{-1}$ of either $V$. dahliae V781I or V152I isolates for $20 \mathrm{~min}$. Conidia were obtained from 7- to 10-day-old cultures in potato dextrose broth (PDB), as previously described (39). Plants were transplanted into sterilized soil (sand/loam, 2:1, vol/vol) in sterilized 3-liter clay pots $(16.5 \mathrm{~cm}$ in diameter by $15.5 \mathrm{~cm}$ in height), and incubated in a walk-in growth chamber adjusted to $24 \pm 1{ }^{\circ} \mathrm{C}$ in light and darkness, 40 to $70 \%$ relative humidity, and a 14-h photoperiod of fluorescent light at $-360 \mu \mathrm{E} \mathrm{m} \mathrm{m}^{-2} \mathrm{~s}^{-1}$. Plants were watered every 1 to 2 days as needed and fertilized weekly with of Hoagland's nutrient solution at $110 \mathrm{ml} /$ pot (21). The experiment was arranged as a completely randomized design. The severity of symptoms was assessed on a 0 -to- 4 scale $(0=$ no symptoms, $1=1$ to $33 \%$ symptomatic leaves and twigs, $2=34$ to $66 \%$ symptomatic, $3=67$ to $100 \%$ symptomatic, and $4=$ dead plant) at 35 and 122 days after inoculation (39).

Isolation of $\mathrm{V}$. dahliae from inoculated plants. The roots and stems of inoculated olive plants were sampled separately in a time course after inoculation for isolation and real-time PCR quantification of $V$. dahliae. Three plants were destructively sampled at
0,6 , and $24 \mathrm{~h}$ and $2,3,7,10,15,21$, and 35 days after inoculation with the two $V$. dahliae pathotypes. Colonization of plant tissues by $V$. dahliae was determined in each sampled plant by isolating the fungus on CWA. For each plant, four 5-mm-long root and stem pieces were thoroughly washed under running tap water for $30 \mathrm{~min}$, surface disinfested in $0.5 \% \mathrm{NaClO}$ for $1.5 \mathrm{~min}$ (stems) or 2 min (roots), rinsed with sterile water, plated onto the medium, and incubated at $25^{\circ} \mathrm{C}$ in the dark for 9 to 21 days (39). For stem pieces, the bark was removed with a clean scalpel before disinfestation. The plated stem pieces were representative of the middle and lower parts of the total length of the sampled stems. Root pieces were arbitrarily chosen from the sampled plants. Bark was not removed from root pieces. The identity of $V$. dahliae was confirmed by microscopic observations of verticillate conidiophores and by the formation of microsclerotia.

Data from the stem and root isolations of the pathogen were used to calculate an index of colonization (IC) determined as IC $=$ $\Sigma(\mathrm{Ti} \times \mathrm{Nj}) /(\mathrm{T} \times \mathrm{N}) \times 100$, where $\mathrm{Ti}$ is the number of root or stem pieces from which the pathogen was isolated, $\mathrm{Nj}$ is the number of plants from which the $\mathrm{Ti}$ pieces were obtained, $\mathrm{T}$ is the total

TABLE 3. Regression equation parameters from standard curves of Verticillium dahliae DNA, sensitivity, specificity and weighted score index (WSI) of five real time quantitative polymerase chain reaction (qPCR) assays evaluated for quantification of V. dahliae in asymptomatic olive infections ${ }^{\mathrm{u}}$

\begin{tabular}{|c|c|c|c|c|c|c|c|c|c|c|c|c|c|c|}
\hline \multirow[b]{2}{*}{ Protocol $^{\mathrm{v}}$} & \multicolumn{4}{|c|}{ Regression parameter } & \multirow[b]{2}{*}{$\mathrm{DL}^{\mathrm{y}}$} & \multicolumn{8}{|c|}{ Specificity $^{w}$} & \multirow[b]{2}{*}{$\mathrm{WSI}^{\mathrm{z}}$} \\
\hline & Intercept & -Slope & $R^{2}$ & $\mathrm{AE}(\%)^{\mathrm{x}}$ & & $G n$ & Vaa & $V a$ & $V i$ & Vna & $V n$ & $V l$ & $V t$ & \\
\hline \multicolumn{15}{|l|}{$\mathrm{SCP}$} \\
\hline Water & $22.75-22.90$ & $4.04-3.78$ & $0.968-0.992$ & $76.8-99.0$ & 1 & $\ldots$ & $\ldots$ & $\ldots$ & $\ldots$ & $\ldots$ & $\ldots$ & $\ldots$ & $\ldots$ & $19.0-19.0$ \\
\hline Stem & $22.18-26.25$ & $3.84-3.44$ & $0.973-0.772$ & $82.1-95.4$ & 1 & $\ldots$ & $\ldots$ & $\ldots$ & $\ldots$ & $\ldots$ & $\ldots$ & $\ldots$ & $\ldots$ & $18.0-19.0$ \\
\hline Leaf & $23.90-27.58$ & $3.78-3.72$ & $0.992-0.673$ & $84.0-85.8$ & 1 & $\ldots$ & $\ldots$ & $\ldots$ & $\ldots$ & $\ldots$ & $\ldots$ & $\ldots$ & $\ldots$ & $16.0-19.0$ \\
\hline Root & - & $\ldots$ & - & - & - & $\ldots$ & $\ldots$ & $\ldots$ & $\ldots$ & $\ldots$ & $\ldots$ & $\ldots$ & $\ldots$ & $0.00-0.00$ \\
\hline Mean & 24.33 & 3.76 & 0.876 & 84.79 & 1 & No & Yes & No & No & No & Yes & No & No & $13.75 \mathrm{bc}$ \\
\hline \multicolumn{15}{|l|}{ SYBR-1 } \\
\hline Water & $12.18-13.40$ & $3.60-3.67$ & $0.996-0.997$ & $87.2-89.6$ & 0.1 & $\ldots$ & $\ldots$ & $\ldots$ & $\ldots$ & $\ldots$ & $\ldots$ & $\ldots$ & $\ldots$ & 21.0-21.0 \\
\hline Stem & $12.57-13.42$ & $3.28-3.55$ & $0.996-0.999$ & $91.2-101.7$ & 0.1 & $\ldots$ & $\ldots$ & $\ldots$ & $\ldots$ & $\ldots$ & $\ldots$ & $\ldots$ & $\ldots$ & $21.0-23.0$ \\
\hline Leaf & $11.94-14.10$ & $3.50-3.37$ & $0.994-0.998$ & $93.1-98.0$ & 0.1 & $\ldots$ & $\ldots$ & $\ldots$ & $\ldots$ & $\ldots$ & $\ldots$ & $\ldots$ & $\ldots$ & $21.0-23.0$ \\
\hline Root & $17.59-18.40$ & $3.51-3.61$ & $0.944-0.957$ & $89.2-92.6$ & 0.1 & $\ldots$ & $\ldots$ & $\ldots$ & $\ldots$ & $\ldots$ & $\ldots$ & $\ldots$ & $\ldots$ & $20.0-21.0$ \\
\hline Mean & 13.60 & 3.45 & 0.985 & 92.83 & 0.1 & Yes & Yes & No & No & No & Yes & No & No & $21.38 \mathrm{~b}$ \\
\hline \multicolumn{15}{|l|}{ SYBR-2 } \\
\hline Water & $24.54-26.79$ & $3.04-3.74$ & $0.736-0.996$ & $85.2-113.1$ & 1 & $\ldots$ & $\ldots$ & $\ldots$ & $\ldots$ & $\ldots$ & $\ldots$ & $\ldots$ & $\ldots$ & $36.0-36.0$ \\
\hline Stem & - & $\ldots$ & - & - & - & $\ldots$ & $\ldots$ & $\ldots$ & $\ldots$ & $\ldots$ & $\ldots$ & $\ldots$ & $\ldots$ & $0.0-0.0$ \\
\hline Leaf & $23.85-24.40$ & $5.35-3.91$ & $0.823-0.955$ & $53.9-80.3$ & 1 & $\ldots$ & $\ldots$ & $\ldots$ & $\ldots$ & $\ldots$ & $\ldots$ & $\ldots$ & $\ldots$ & $35.0-36.0$ \\
\hline Root & - & $\ldots$ & - & - & - & $\ldots$ & $\ldots$ & $\ldots$ & $\ldots$ & $\ldots$ & $\ldots$ & $\ldots$ & $\ldots$ & $0.0-0.0$ \\
\hline Mean & 24.90 & 4.01 & 0.870 & 83.10 & 1 & Yes & Yes & Yes & Yes & Yes & Yes & No & Yes & $17.88 \mathrm{c}$ \\
\hline \multicolumn{15}{|l|}{ SYBR-4 } \\
\hline Water & $21.43-21.39$ & $3.33-3.34$ & $0.973-0.986$ & $99.3-99.8$ & 0.1 & $\ldots$ & $\ldots$ & $\ldots$ & $\ldots$ & $\ldots$ & $\ldots$ & $\ldots$ & $\ldots$ & $43.0-43.0$ \\
\hline Stem & $21.41-21.48$ & $3.34-3.27$ & $0.993-0.992$ & $99.4-102.4$ & 0.1 & $\ldots$ & $\ldots$ & $\ldots$ & $\ldots$ & $\ldots$ & $\ldots$ & $\ldots$ & $\ldots$ & $43.0-43.0$ \\
\hline Leaf & $21.03-21.63$ & $3.26-3.31$ & $0.981-0.995$ & $100.6-102.8$ & 0.1 & $\ldots$ & $\ldots$ & $\ldots$ & $\ldots$ & $\ldots$ & $\ldots$ & $\ldots$ & $\ldots$ & $43.0-43.0$ \\
\hline Root & $21.21-21.34$ & $3.17-3.17$ & $0.995-0.989$ & $100.7-106.9$ & 0.1 & $\ldots$ & $\ldots$ & $\ldots$ & $\ldots$ & $\ldots$ & $\ldots$ & $\ldots$ & $\ldots$ & $41.0-43.0$ \\
\hline Mean & 21.36 & 3.27 & 0.990 & 100.80 & 0.1 & Yes & Yes & Yes & Yes & Yes & Yes & No & Yes & $42.75 \mathrm{ab}$ \\
\hline \multicolumn{15}{|l|}{ TAQ } \\
\hline Water & $15.06-15.27$ & $3.39-3.60$ & $0.971-0.996$ & $89.7-97.0$ & 0.1 & $\ldots$ & $\ldots$ & $\ldots$ & $\ldots$ & $\ldots$ & $\ldots$ & $\ldots$ & $\ldots$ & $46.0-48.0$ \\
\hline Stem & $14.69-14.76$ & $3.61-3.62$ & $0.990-0.996$ & $88.7-89.2$ & 0.1 & $\ldots$ & $\ldots$ & $\ldots$ & $\ldots$ & $\ldots$ & $\ldots$ & $\ldots$ & $\ldots$ & $46.0-48.0$ \\
\hline Leaf & $14.46-14.84$ & $3.55-3.64$ & $0.981-0.994$ & $88.0-91.2$ & 0.1 & $\ldots$ & $\ldots$ & $\ldots$ & $\ldots$ & $\ldots$ & $\ldots$ & $\ldots$ & $\ldots$ & $46.0-46.0$ \\
\hline Root & $15.09-15.61$ & $3.15-3.60$ & $0.822-0.990$ & $89.6-107.9$ & 0.1 & $\ldots$ & $\ldots$ & $\ldots$ & $\ldots$ & $\ldots$ & $\ldots$ & $\ldots$ & $\ldots$ & $46.0-48.0$ \\
\hline Mean & 14.97 & 3.52 & 0.968 & 92.68 & 0.1 & Yes & Yes & Yes & Yes & Yes & Yes & Yes & Yes & $46.75 \mathrm{a}$ \\
\hline
\end{tabular}

" Standard curves were obtained by five-point 10-fold serial dilution of V. dahliae DNA of isolates V781I and V152I (10 ng/ $\mu$ l) to obtain $1 \mathrm{ng}$ to $0.1 \mathrm{pg}$ of DNA per PCR reaction diluted in sterile distilled water or in DNA extracted from olive leaves and stems (10 ng of background DNA) or roots (5 ng of background DNA) to investigate any possible influence of host DNA on sensitivity of PCR reactions.

$\checkmark$ qPCR protocol and background DNA.

${ }^{w}$ No indicates that the protocol is not specific and cross-amplified Gibellulopsis nigrescens (Gn), V. albo-atrum (Vaa), V. alfalfae (Va), V. isacii (Vi), V. longi$\operatorname{sporum}(V l), V$. nonalfalfae $(V n a), V$. nubilum $(V n)$, and $V$. tricorpus $(V t)$. Yes indicates that the protocol was specific for $V$. dahliae.

${ }^{x}$ Amplification efficiency (AE) was calculated from the slopes of the standard curves using the equation $\mathrm{AE}=10^{(-1 / \text { slope })}-1(1,20)$. Range corresponds to results from two independent standard curves, each performed by two independent operators and four replications within each plate.

${ }^{y}$ Detection limit $(\mathrm{pg} / \mu \mathrm{l})$.

${ }^{\mathrm{z}}$ Score system $=$ points were given for each of the qPCR amplification traits that were consider important to choose a protocol as the most appropriate for our amplifications purposes: $R^{2}$ (score $0=$ no amplification; score $1=R^{2}<0.85$; score $2=0.85<R^{2}<0.95$; score $3=R^{2}>0.95$ ); AE (score 0 , no amplification; score $1, \mathrm{AE}<85 \%$; score 2, 85\% < AE < 95\%; score 3, AE > 95\%), DL (score 0, no amplification; score $1,1<\mathrm{DL} \leq 10 \mathrm{pg} / \mu \mathrm{l} ;$; score $2,0.1<\mathrm{DL} \leq 1 \mathrm{pg} / \mu \mathrm{l}$; score $3, \mathrm{DL} \leq 0.1 \mathrm{pg} / \mu \mathrm{l})$. Additionally, scores of 0 were given if there was cross-amplification for the other eight Verticillium spp. different from V. dahliae that we tested, whereas a score of 1 was given if there was no cross-amplification for those species. Then, a WSI was calculated by using weights of $1,2,3$, and 4 for $R^{2}$, $\mathrm{AE}, \mathrm{DL}$, and total specificity score, respectively, indicating the importance given to each parameter to appropriately quantify $V$. dahliae DNA in asymptomatic plant tissues under our experimental conditions. A total WSI of 54 points was possible. A Kendall-concordance analysis was performed using the WCI values obtained for each DNA background and experiment. Range corresponds to results from to two independent standard curves, each performed by two independent operators and four replications within each plate. Values followed by the same letter are not significantly different $(P=0.05)$. 
number of pieces processed, and $\mathrm{N}$ is the total number of sampled plants. IC data were plotted over time in days to obtain vascular colonization progress curves.

All stem and root tissues of each sampled plant were immediately stored at $-80^{\circ} \mathrm{C}$ for real-time PCR quantification assays.

In planta real-time PCR quantification of $D$ and $N D \mathrm{~V}$. dahliae. Total DNA was extracted from $50 \mathrm{mg}$ of lyophilized stems and roots of inoculated and noninoculated Frantoio plants. Extracted olive DNA was quantified using the Quant-iT DNA Assay Kit Broad Range fluorometric assay as described above and diluted to $\approx 20 \mathrm{ng} / \mu \mathrm{l}$ for stem samples or to $5 \mathrm{ng} / \mu \mathrm{l}$ for root samples. The amount of $V$. dahliae DNA in each sample was estimated using the SYBR-4 (3) and TAQ (6) qPCR protocols that were selected as the most efficient in the previous experiments for asymptomatic quantification of different $V$. dahliae isolates in the two types of olive tissues.

Amplification reactions were performed in 96-well microtiter plates. Three independent plant samples and two simultaneous, replicated amplifications were carried out for each DNA sample. Each plate contained all DNA samples corresponding to a single $V$. dahliae pathotype and tissue (stems or roots) assayed, and every reaction in the plate was made up using aliquots of the same master mix. Thus, all DNA samples (and their replicates) were subjected to the same experimental conditions. Additionally, each plate always contained the DNA standard curves obtained as described above, as well as DNA samples from noninoculated olive plants and a negative control reaction (no template DNA) that were used to test for interplate variability.

Additionally, to test for the absence of PCR inhibitors in the samples, the $\beta$-actin gene from olive was amplified using Act1fw/Act1-rv primers (46). Results from quantification of the $\beta$-actin were referred to a DNA standard curve obtained as described above from six twofold dilutions of olive DNA $(20 \mathrm{ng} / \mu \mathrm{l})$ in sterile ultrapure water. These results were used to calibrate the quantification of $V$. dahliae DNA to the real amount of olive DNA template added to each qPCR assay (Supplemental Figure 1).

Data analyses. In the real-time qPCR assays, the cycle threshold $\left(\mathrm{C}_{\mathrm{T}}\right)$ values for each reaction were calculated first by determining the PCR cycle number at which the fluorescence signal exceeded the background using the default estimation criteria in the iCycler IQ software (version 3.0a; Bio-Rad). Then, to compare and establish relationships among the different DNA standard curves generated from different treatments, the threshold position was manually defined and fixed at the same position for all treatments and experiments (52). The amplification efficiency (AE) was calculated from the slopes of the standard curves using the equation $\mathrm{AE}=10^{(-1 / \text { slope })}-1(1,20)$.

All data analyses were performed using Statistix v9.0 (NH Analytical Software, Roseville, MN). Linear regressions of the natural logarithm of known concentrations of the target DNA versus the $C_{T}$ values were performed for each DNA dilution series. Standard regression lines from each plate chosen as reference curves were used for transforming the experimental $C_{T}$ values into amounts of pathogen DNA (nanograms). All standard regression lines obtained for fungal genomic DNA in different backgrounds (water, stem, leaf, and root) were statistically compared for homogeneity $(P \geq 0.05)$ of variance (Bartlett's test) and for equality of slopes and intercepts using an $F$ test at $P<0.05$.

Additionally, to objectively assess each protocol for selecting the most appropriate for our amplifications purposes, a score system was used whereby scores were assigned to each of the qPCR amplification traits that were considered important: $R^{2}$ (score 0 , no amplification; score $1, R^{2}<0.85$; score 2, $0.85<R^{2}<0.95$; score $3, R^{2}>0.95$ ), AE (score 0, no amplification; score $1, \mathrm{AE}<$ $85 \%$; score 2, 85\% < $\mathrm{AE}<95 \%$; score 3, $\mathrm{AE}>95 \%$ ), and detection limit (DL) (score 0, no amplification; score $1,1<\mathrm{DL} \leq$ $10 \mathrm{pg} / \mu \mathrm{l}$; score 2, $0.1<\mathrm{DL} \leq 1 \mathrm{pg} / \mu \mathrm{l}$; score $3, \mathrm{DL} \leq 0.1 \mathrm{pg} / \mu \mathrm{l})$. Also, a score 0 was assigned if there was cross-amplification for any of the eight Verticillium spp. other than V. dahliae tested and a score of 1 if there was no cross-amplification for each of those species (a maximum score of 8 was possible for specificity; Supplemental Figure 2). Then, each score was weighted with 1, 2, 3, and 4 for $R^{2}, \mathrm{AE}, \mathrm{DL}$, and specificity, respectively, to indicate the weight (importance) given to each parameter for appropriately quantifying $V$. dahliae DNA in asymptomatic plant tissues. A total weighted score index (WSI) of 54 points was possible. Finally, a Kruskal-Wallis one-way nonparametric analysis of variance was performed to test for significance $(P<0.05)$ of the differences among the various protocols for the WSI.

In addition, the area under the IC curve (AUIC) plotted over time of sampling (estimated by positive pathogen isolation), as well as the area under the curve of the amount of $V$. dahliae DNA in olive tissue (AUAVDC) plotted over time of sampling (estimated by qPCR), were used to assess for significance of the differences among $\mathrm{D}$ and ND $V$. dahliae isolates by using Fisher's protected least significant difference at $P<0.05$.

\section{RESULTS}

Comparison of real-time $\mathrm{qPCR}$ protocols for the quantification of $\boldsymbol{V}$. dahliae. SYBR-3 (31), SYBR-5 (17), and SYBR-6 (35) protocols were initially screened but were rejected from further real-time evaluation because they showed cross-amplification with several Verticillium spp. or G. nigrescens (Supplemental Figure 2), as well as overall lack of reproducibility, or low sensitivity (data not shown). Similarly, under the conditions employed in this study, we found that primers Vd10 and Vd7b used in protocols SCP and SYBR-1 also cross-amplified DNA from some Verticillium spp. However, those two protocols were included in the analyses together with protocols SYBR-2 (37), SYBR-4 (3), and TAQ (6) because they performed well in the preliminary experiments (data not shown).

The performance characteristics of each assayed protocol and the weighted scores to select the most appropriate technique for the quantification of $V$. dahliae in asymptomatic olive tissues are listed in Table 3 . The efficiency and reproducibility of some of real-time qPCR assays standard regression were significantly $(P<$ 0.05 ) influenced by the presence of the host DNA (i.e., extracted from stem, leaf, and root tissues) (Table 3). PCR inhibition occurred for protocols SCP (42) and SYBR-2 (37) using root DNA, as well as for protocol SYBR-2 using stem DNA. Thus, a low reproducibility of amplifications occurred for those protocols and we failed obtaining a linear dynamic range of amplification after three orders of magnitude of DNA concentration (data not shown). Consequently, standard regression lines for those DNA backgrounds were not estimated (Table 3). Conversely, for the remaining SYBR-1 (this study), SYBR-4 (3), and TAQ (6) protocols, we achieved high reproducibility of amplifications $\left(0.88>R^{2}>0.99\right)$ with high efficiency $(87.2>\mathrm{AE}(\%)>107.9)$ over five orders of magnitude of DNA concentration for the different experiments and DNA backgrounds, which exhibited a linear dynamic range of amplification (Fig. 1; Table 3). V. dahliae DNA was accurately quantified at a concentration of $0.1 \mathrm{pg}$ either if DNA was diluted in water or in DNA extracted from olive stem, leaf, or root tissues (Fig. 1; Table 3). V. dahliae DNA could also be quantified to $0.01 \mathrm{pg}$ with the three protocols but the reproducibility of amplifications decreased at this lower concentration (data not shown); therefore, we fixed the limit of detection at the estimated $\mathrm{C}_{\mathrm{T}} \mathrm{S}$ corresponding to this concentration (i.e., $\mathrm{C}_{\mathrm{T}}=32$ or 36 for SYBR-1 and TAQ or SYBR-4 protocols, respectively) (Fig. 1).

Finally, the five q-PCR protocols were ranked according to a weighted score system (WSI) and analyzed together for both experiments and each of the DNA backgrounds: SYBR-4 (3) and TAQ (6) ranked first, followed by SYBR-1 (this study) (mean WSI of 46.8, 42.8, and 21.4, respectively), although there were no significant $(P \geq 0.05)$ differences among SYBR-4 (3) and TAQ (6) 
protocols (Table 3). Comparisons of the four standard regression lines within each of the protocols TAQ, SYBR-1, and SYBR-4 showed no significant differences among slopes or intercepts $(P>$ $0.3790)$ for DNA template tested in the background of olive DNA from several tissues (stem, leaf, or root) (Table 3), suggesting that the performance of these three protocols was not influenced by the presence of host DNA (Table 3; Fig. 1). Finally, comparison of standard regression lines among protocols indicate that there were significant differences among intercepts $(P<0.001)$ but not among slopes $(P>0.1931)$. The lower value of intercept for protocol SYBR-1 and TAQ compared with that of SYBR-4 indicate a significantly higher $(P<0.05)$ sensitivity of the former two protocols.
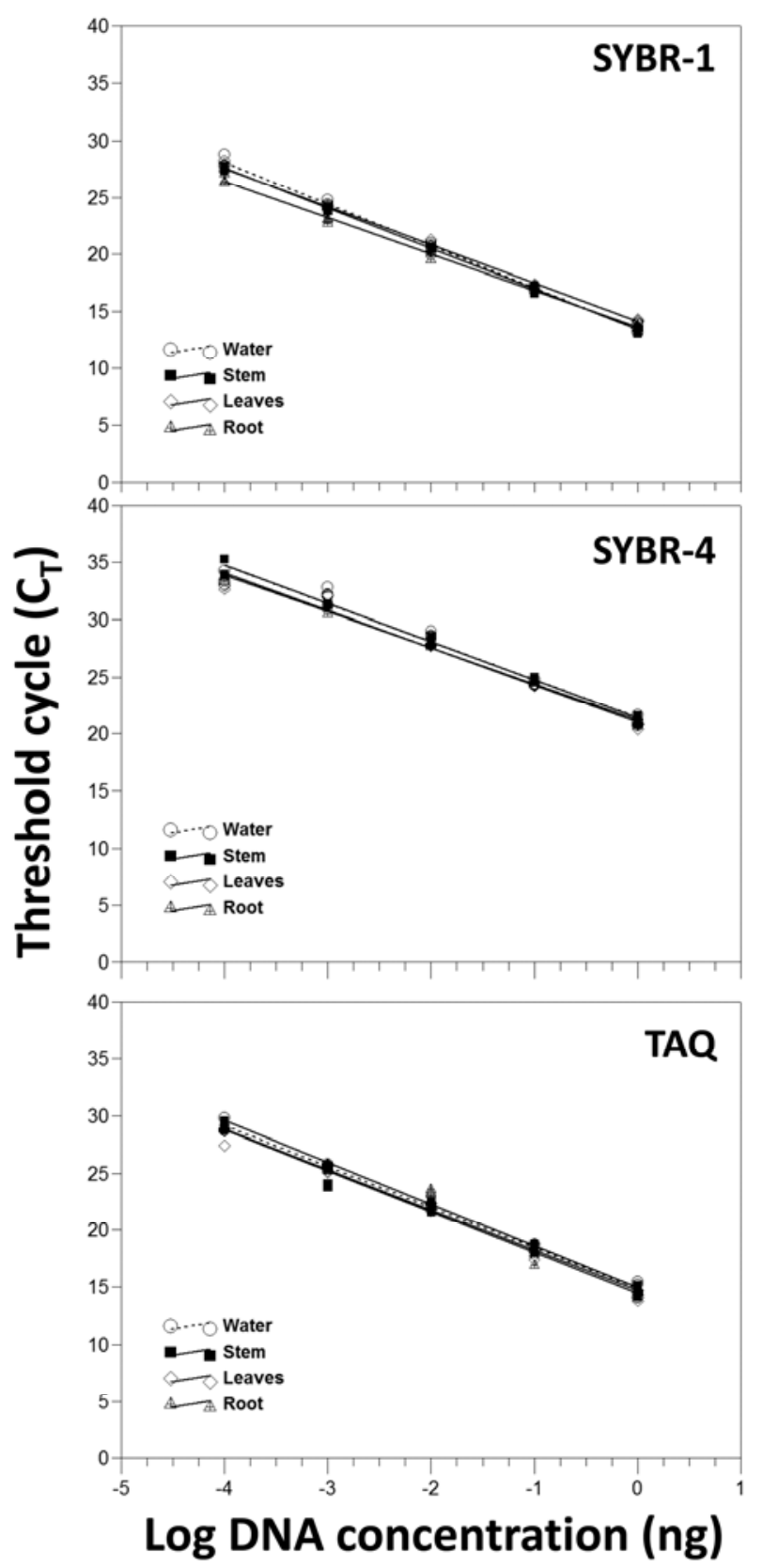

Fig. 1. Standard regression lines of a five-point 10 -fold serial dilution of Verticillium dahliae (V781I) DNA (10 ng/ $\mu$ l) diluted in sterile, ultrapure water (Water series) or in DNA (20 ng) extracted from olive stems and leaves, or in DNA (5 ng) extracted from olive roots obtained with the SYBR-1 (this study) and SYBR-4 (3) and TAQ (6) quantitative polymerase chain reaction protocols. Cycle thresholds $\left(\mathrm{C}_{\mathrm{T}}\right)$ were plotted against the log of genomic DNA standard curves of known concentrations. Data shown are from a representative experiment.
Finally, we selected the SYBR-4 protocol (based on the singlecopy gene $\beta$-tubulin) and the TAQ protocol (based on the multicopy region of ribosomal DNA [rDNA]) for subsequent analyses based on their increased specificity compared with SYBR-1 (Table 3). In silico analysis of the race 2 strain of $V$. dahliae, VdLs.17 genome has recently revealed that the VertBt primer pair occurs once (27).

Development of Verticillium wilt in Frantoio olive plants. Symptoms were absent in noninoculated plants after 35 and 122 days of incubation. Plants inoculated with $V$. dahliae were also asymptomatic at 35 days after inoculation. At 122 days after inoculation, two plants inoculated with $\mathrm{D} V$. dahliae had a symptom severity score of 1 and 0.5 , respectively, and one plant inoculated with ND V. dahliae had a symptom severity score of 1.5 .

Isolations from inoculated plants indicated that infection of the root system by D and ND V. dahliae took place soon after inoculation. Thus, infections of root tissues by $\mathrm{D}$ and ND $V$. dahliae amounted to 15 and $50 \%$, respectively, just after inoculation, and then increased to $55 \%$ for $\mathrm{D} V$. dahliae at 2 and 10 days after inoculation and to $20 \%$ for ND $V$. dahliae at 2 and 15 days after inoculation. By 35 days after inoculation, percent root infections by D $V$. dahliae was $40 \%$, whereas isolations failed to recover ND $V$. dahliae from root tissues at that same sampling time. The total amount of positive isolations estimated by the AUIC was significantly $(P<0.001)$ higher in roots inoculated with $\mathrm{D} V$. dahliae than in those inoculated with ND V. dahliae (Fig. 2), with average infections per plant across the sampling period of 34.5 and $11.0 \%$ for $\mathrm{D}$ and ND V. dahliae, respectively.

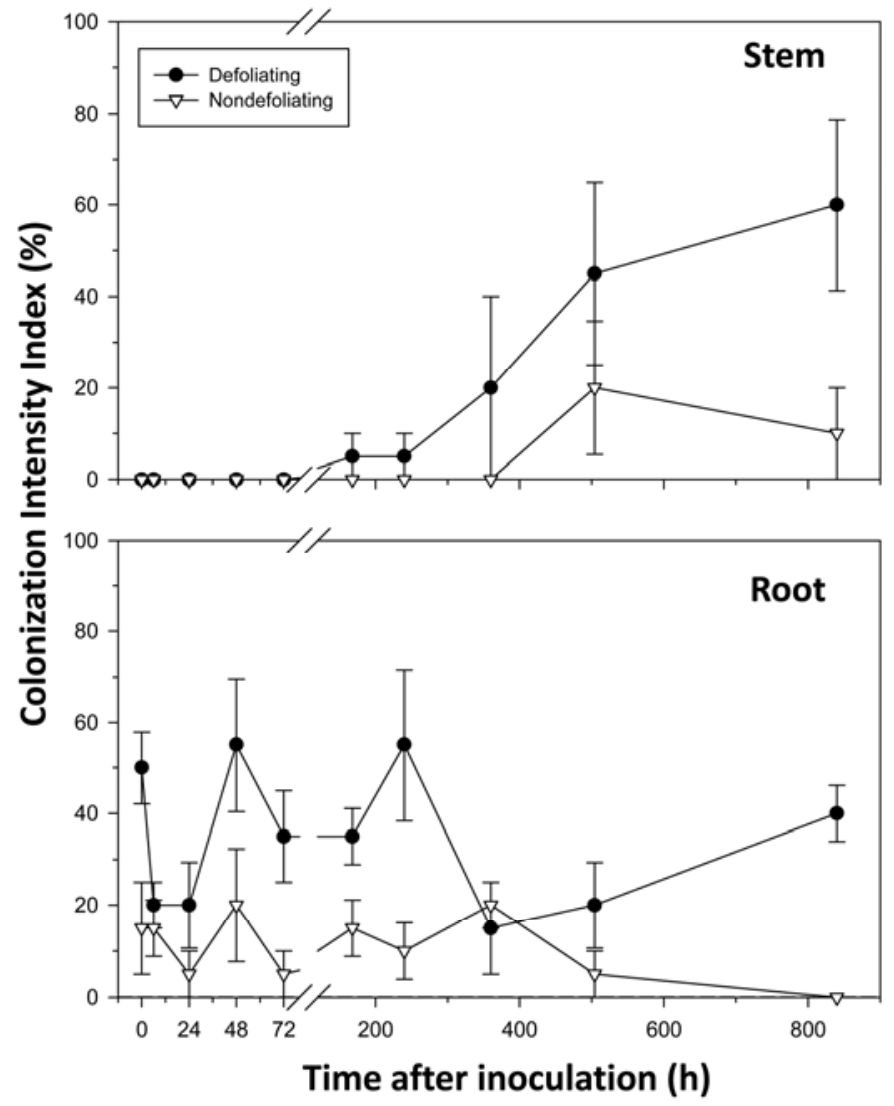

Fig. 2. Colonization of roots and stems of 'Frantoio' olive plants by Verticillium dahliae isolates V781I (defoliating pathotype) and V152I (nondefoliating pathotype). An index of colonization $[\mathrm{IC}=\Sigma(\mathrm{Ti} \times \mathrm{Nj}) /(\mathrm{T} \times \mathrm{N}) \times 100]$ was calculated and plotted over time, where $\mathrm{Ti}$ is the number of plant pieces from which the pathogen was isolated, $\mathrm{Nj}$ is the number of plants from which the $\mathrm{Ti}$ stems or root pieces were obtained, $\mathrm{T}$ is the total number of plant pieces processed, and $\mathrm{N}$ is the total number of sampled plants. Each plotted point is the mean \pm standard deviation value of five plants. 
In contrast, the first $V$. dahliae isolation from stem was observed at 7 and 21 days after inoculation with D and ND $V$. dahliae, respectively. Later on, the IC in stems infected by the D $V$. dahliae pathotype steadily increased to $60 \%$ by the end of the bioassay, 35 days after inoculation. In contrast, the highest IC for ND V. dahliae was estimated at $20 \%$ by 21 days after inoculation. Globally, the AUIC was significantly $(P<0.001)$ higher in D $V$. dahliae infected stems compared with that in ND $V$. dahliae infected ones (Fig. 2).

Quantification of D and ND $V$. dahliae DNA in infected Frantoio olive plants by qPCR. All DNA samples extracted from olive root and stem tissues were suitable for qPCR experiments. Results of real-time qPCR assays using the SYBR-4 (3) and TAQ (6) qPCR protocols and samples of total genomic DNA extracted from stem and root tissues of D and ND $V$. dahliae inoculated plants are shown in Figure 3. Comparison of slopes and intercepts of regression lines generated for each protocol and DNA standard curves using a range of $V$. dahliae DNA (from $1 \mathrm{ng}$ to $0.1 \mathrm{pg}$ ) in each of the assayed backgrounds showed no significant differences $(P>0.05)$ among all qPCR plates used, which allowed combining results from all experiments for analyses. For this assay, we fixed the detection limit at a $\mathrm{C}_{\mathrm{T}}$ of 36 , corresponding to $\approx 18$ and $15 \mathrm{fg}$ of $V$. dahliae DNA for SYBR-4 and TAQ protocols, respectively.

Both protocols yielded a similar trend in the amount of DNA of $V$. dahliae pathotypes quantified in olive tissues, with just some small differences that, overall, were not significant $(P>0.05)$ (Fig. 3). The amount of $V$. dahliae DNA differed significantly $(P$ $<0.05)$ among roots and stems sampled from plants inoculated with D or ND $V$. dahliae at the different sampling times, being highest for root tissues. In roots and stems, the amount of DNA of $\mathrm{D}$ and ND $V$. dahliae was highest at 10 days after inoculation. Globally, for both protocols, the total amount of $V$. dahliae DNA in root tissues estimated by the AUAVDC was significantly $(P<$ 0.0001) higher for the ND pathotype than the D one (Fig. 3), with mean values of 196 (SYBR-4) and 202 (TAQ) or of 40 (SYBR-4) and 35 (TAQ) ng of $V$. dahliae DNA per nanogram of olive root DNA, for the ND and D pathotypes, respectively. In contrast, for stems tissues, significantly $(P<0.005)$ higher AUAVDC values were estimated for $\mathrm{D} V$. dahliae compared with that of ND $V$. dahliae (Fig. 3), with mean values of 48 (SYBR-4) and 46 (TAQ) or 5 (SYBR-4) and 8 (TAQ) ng of $V$. dahliae DNA per nanogram of olive stem DNA for the D and ND pathotypes, respectively.

In general, the amount of D and ND $V$. dahliae DNA in stems remained stable throughout the duration of the experiment, with the highest value occurring at 10 days after inoculation. Overall, in all olive tissues tested, $V$. dahliae DNA amount tended to slightly decrease or was stable by the end of the experiment, 35 days after inoculation.

\section{DISCUSSION}

Results of this comparative study demonstrated that some of the real-time qPCR protocols published in the last 10 years are not specific for $V$. dahliae or are inhibited when used in a background of plant tissue extracts. The study also selected two robust protocols $(3,6)$ that were efficient in monitoring colonization of symptomless Frantoio olive plants by D and ND $V$. dahliae in a time course after inoculation.

Under our experimental conditions, protocols SYBR-1 (this study), SYBR-4 (3), and TAQ (6) performed best according to a WSI established for their objective evaluation (Table 3). The protocols were evaluated using $R^{2}, \mathrm{AE}, \mathrm{DL}$, and specificity.

When testing specific real-time qPCR protocols, it is important to determine that $\mathrm{AE}$, sensitivity and reproducibility are not influenced by the presence of nontarget DNA from different sources (either plant or soil DNA). We statistically compared the slope and intercept parameters of the standard regression lines obtained for $V$. dahliae genomic DNA dilution series in a background of olive stem, leaf, or root DNA. A similar approach of validation procedure was used recently by other authors $(3,13,40)$. Thus, statistical analysis of the obtained DNA standard regression lines

\section{SYBR-4 Protocol}

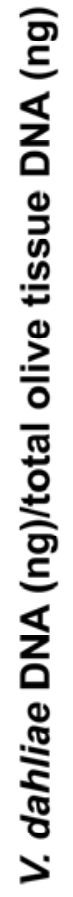

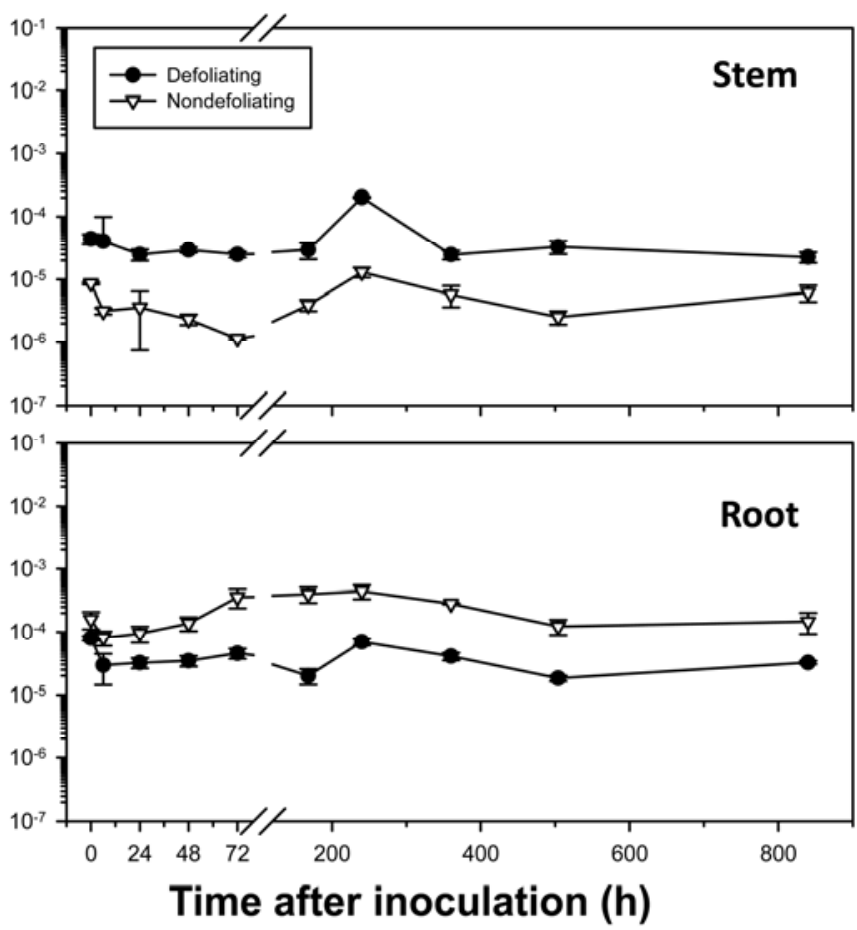

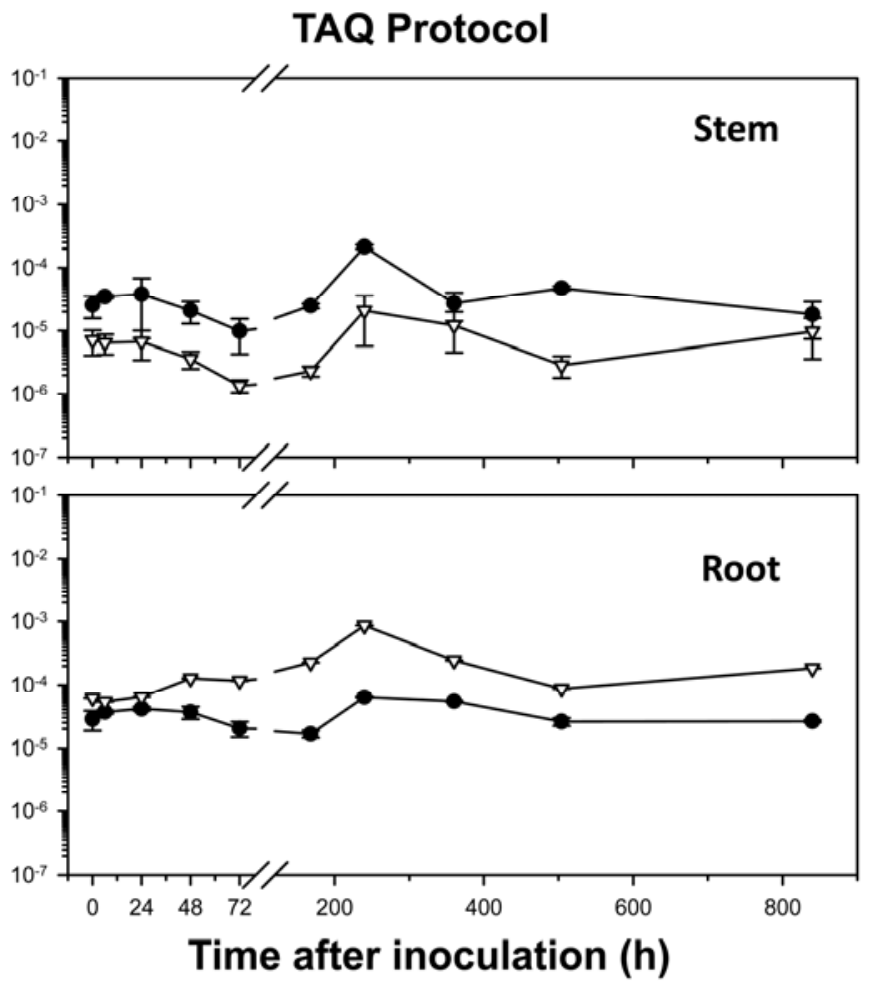

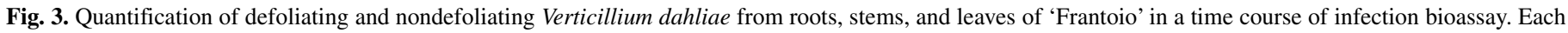

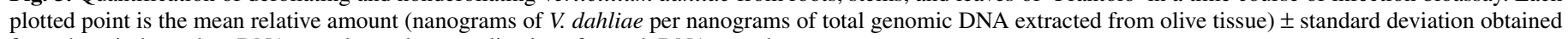
from three independent DNA samples and two replications for each DNA sample. 
indicated that neither background olive stem, leaf, or root DNA nor the operator performing assays significantly influenced performance of SYBR-4 (3), SYBR-1 (42), and TAQ (6) protocols demonstrating their robustness. Also, we demonstrated that sensitivity of the protocols was not affected by the plant tissue assayed because we could detect the fungus and quantify $\leq 100 \mathrm{fg}$ of $V$. dahliae DNA in olive stem and root for SYBR-4 and TAQ protocols without loss of accuracy. A detection limit similar to that of the original protocol SYBR-4 was reported by Atallah et al. (3), who detected $\leq 148$ fg of $V$. dahliae DNA in a background of potato tissue, which correspond to five nuclei based upon one genome in each nucleus $\approx 28 \mathrm{fg}$ (48). The VertBt primers used in protocol SYBR-4 were recently applied with the use of an analytical grinder and an external control of spinach actin target DNA to quantify $V$. dahliae in spinach seed (13), showing a sensitivity limit of 1 infected seed per 100 seeds (i.e., $\approx 29$ nuclei or 812 fg of DNA).

Other real-time qPCR protocols (i.e., SYBR-1, SYBR-2, SYBR-6, and SCP) assayed in this present study under our experimental conditions had shown lesser specificity or sensitivity levels for detection of $V$. dahliae in olive compared with that of SYBR-4 and TAQ. Thus, the high specificity and sensitivity of TAQ and SYBR-4 protocols make them suitable for accurately detecting and quantifying $V$. dahliae in asymptomatic reactions or incompatible combinations, for which the amount of pathogen DNA is expected to be rather low. Protocols SYBR-1 and TAQ were more sensitive than SYBR-4 because the intercepts of the standard DNA regression lines of those assays were significantly lower than that of SYBR-4. The higher sensitivity of SYBR-1 and TAQ protocols may result from the primers developed for them targeting the intergenic spacer (IGS) region of the rDNA occurring in multicopies. The fact that such targets within the rDNA occur in high copy numbers makes PCR assays using primers derived from rDNA regions easy, sensitive, and reliable in the detection of fungal pathogens. However, it should be taken into account that the number of rDNA copies in a microorganism may fluctuate with its age and stage of growth (43), as has been reported for different Verticillium spp. $(45,47)$ as well as for different isolates of $V$. dahliae $(6,45)$. For instance, Bilodeau et al. (6) compared the amplification of the rDNA and of several singlecopy genes among isolates of $V$. dahliae and concluded that the number of rDNA copies was $\approx 24$ to 73 per haploid genome (average of $\approx 46$ ), depending upon the isolate. This variation in the copy number among $V$. dahliae isolates, together with findings in this present study of risk with the SYBR-1 protocol of crossamplification with $V$. albo-atrum, $V$. tricorpus, and $V$. longisporum, led us to discard this latter protocol for further assays and to select SYBR-4 (3) and TAQ (6) as the protocols most appropriate for our purposes. One advantage of the SYBR-4 protocol over the TAQ protocol is that the SYBR-4 protocol is based on the nuclear gene $\beta$-tubulin which, in $V$. dahliae, occurs in single copy (27), thus allowing for potential comparisons among samples and consistent pathogen quantification regardless of age, growth stage, and nature of the $V$. dahliae isolate. In fact, Atallah et al. (3) observed that sequences of $\beta$-tubulin 2 provide polymorphisms that separate $V$. dahliae from closely related species such as $V$. albo-atrum and $V$. tricorpus. One possible shortcoming when using the SYBR-4 protocol could be the cross-amplification with $V$. longisporum (13), as we also found in our study. However, natural infections of olive trees by $V$. longisporum, a cruciferspecific pathogen, are yet to be demonstrated $(15,18,24,34,48)$.

The selected SYBR-4 and TAQ protocols were further used for quantitatively monitoring the amount of pathogen DNA in the colonization of reportedly resistant 'Frantoio' by the D and ND $V$. dahliae pathotypes in a time-course infection bioassay. Although previous reports have highlighted the resistance of Frantoio olive to D $(14,32,36)$ and ND (33) V. dahliae pathotypes under artificial and natural infections, in our study, we showed the ability of those two pathotypes to extensively infect and colonize systemically symptomless resistant Frantoio plants that had not been previously documented. This symptomless infection was consistently demonstrated in this present work both by means of direct isolation of the pathogen from stems and roots of inoculated plants on culture and by real-time qPCR assays using the SYBR-4 protocol and total DNA extracted from stems, roots, and leaves of those plants. Mercado-Blanco et al. (37) observed that slight wilt symptom expression of the highly resistant Acebuche-L olive genotype correlated with resistance to infection by the pathogen, as indicated by failure to quantify $V$. dahliae DNA in the stem. In this regard, it is worth mentioning the high inhibition of the primers and SYBR-2 protocol employed by Mercado-Blanco et al. (37) found in our study when spiking the standard curves with stem tissue DNA.

Based on our results, 'Frantoio' should be considered tolerant rather than resistant to $V$. dahliae pathotypes according to the concept of tolerance as a plant's ability to sustain extensive systemic colonization but express few, if any, symptoms and provide a reasonable crop yield $(4,16)$. Nevertheless, the term "tolerance" might still be somehow controversial in Verticillium wilt of olive. Thus, whereas histopathological observations and frequency of $V$. dahliae isolation from olive root and stem convincingly indicated that colonization by the pathogen is hindered in resistant plants, corresponding to true resistance (2,34), Jiménez-Díaz et al. (24) indicated that the resistant reaction of certain olive cultivars does not exclude the pathogen from reaching the upper plant parts and being isolated from symptomatic or symptomless leaves. In our study, lesser amounts of pathogen DNA were quantified in Frantoio olive stem tissues compared with those in root tissues, which agrees with results reported by Mercado-Blanco et al. (37).

Differences in the degree of systemic colonization of resistant and tolerant plants by $V$. dahliae appear to be clearer in herbaceous hosts. For example, assessment of stem colonization in tomato plants by qPCR assay (8), and in Arabidopsis thaliana plants by tissue maceration and plating (53) indicated that the average amount of $V$. dahliae in tolerant plants showing few or no symptoms was very similar to that in susceptible plants but much higher than in the resistant ones. Further studies including more tolerant and resistant olive genotypes are needed to better understand differences in olive- $V$. dahliae interactions leading to true tolerant and resistant reactions.

Monitoring of colonization of symptomless Frantoio plants by $V$. dahliae indicated that differences in virulence of $\mathrm{D}$ and ND pathotypes on susceptible olive cultivars correlated with differences in the amount of $V$. dahliae DNA revealed by the SYBR-4 and TAQ protocols and percentage of positive pathogen isolations. However, the amount of each pathotype biomass varied with the olive tissue assayed. In general, the amount of $V$. dahliae DNA in stems was higher for the D than for the ND pathotype, whereas the opposite occurred for the amount of $V$. dahliae DNA in roots. Also, percentage of positive isolations from root and stem tissues was higher for the highly virulent $D$ isolate than for the less virulent ND one. These findings are in agreement with those of Mercado-Blanco et al. (37), who observed higher average DNA amounts of ND pathotype in roots of 'Arbequina' and 'Picual' olive compared with that of the D pathotype but that the opposite occurred in the stem. Nevertheless, those authors and Markakis et al. (35) concluded that differences in the in planta amount of pathogen DNA was influenced to a larger extent by the olive genotype than by virulence of the infecting D or ND pathotype, suggesting that the extent of pathogen colonization does not solely determine the level of symptom expression or virulence phenotype $(35,37)$.

In this present study, peaks of $V$. dahliae DNA occurred in all sampled tissues at different times after inoculation followed by intermittent periods of decreasing fungal biomass. However, increased pathogen biomass that occurred early in root tissues did 
not exactly correspond to subsequent high $V$. dahliae biomass in stem tissues. The fluctuations in the fungal biomass in Frantoio olive plants observed in this study suggest that the pattern of colonization by $V$. dahliae was cyclical in nature, and similar to that reported for colonization of alfalfa and tomato by $V$. alboatrum (19,22). Nevertheless, significant differences might occur between that pattern in resistant, tolerant, and susceptible reactions. For instance, Heinz et al. (19) observed that substantial amounts of $V$. albo-atrum were present in the upper tissues of resistant tomato plants within 2 to 4 days after root-dip inoculation, and concluded that this initial burst of colonization resulted from the earliest rounds of sporulation by the fungus. Thereafter, a decrease in the amounts of detected pathogen DNA may correspond with partial lysis of Verticillium sp. propagules as a consequence of defense mechanisms in the infected plant that are not sufficient to interfere with subsequent events of fungal conidiogenesis and cyclic colonization during host growth (19, $35,37)$. In our study, we observed a steady and progressive decrease in the amount of $V$. dahliae DNA over time, especially in root tissues, and a complete failure of positive isolation of the $\mathrm{ND}$, which is similar to that reported by Mercado-Blanco et al. (37) and Markakis et al. (35). This decrease in fungal biomass could be attributed to the natural phenomenon of recovery from disease of tolerant genotypes associated with mechanisms that allow olive trees to overcome injury and decay, and can be activated after infections by $V$. dahliae (24).

In conclusion, this present work identified SYBR Green and TAQ protocols targeting the $\beta$-tubulin (3) and the IGS genes, respectively, as superior real-time PCR techniques for the specific detection and quantification of $V$. dahliae in different asymptomatic tissues of resistant or tolerant olive genotypes. The procedures used in this study revealed the presence of $V$. dahliae in upper tissues of symptomless plants, which makes implementation of these techniques suitable for certification schemes of pathogen-free planting material as well as breeding programs for development of new olive genotypes highly resistant to the D pathotype of $V$. dahliae, the current most important pathogen for olive production.

\section{ACKNOWLEDGMENTS}

Financial support for this research was provided by Project AGL200800344 and AGL-2012-37521 from 'Ministerio de Ciencia e Innovación and Ministerio de Economia y Competitividad'; Projects P10-AGR5908 and P10-AGR6082 from 'Consejería de Economía, Innovación y Ciencia' of Junta de Andalucía and the European Social Fund. D. Gramaje is the recipient of a JAE-DOC postdoctoral contract from 'Consejo Superior de Investigaciones Científicas' (CSIC) cofunded by the European Social Fund. The 'Interprofesional del Aceite de Oliva Español' and 'Fundacion CITOLIVA' also provided partial financial support. We thank all colleagues listed in Table 2 for providing us with cultures or DNA of isolates of Verticillium spp. and F. Nigro for providing the scorpion primer for testing the SCP protocol.

\section{LITERATURE CITED}

1. Adams, P. S. 2006. Data analysis and reporting. Pages 39-62 in: RealTime PCR. M. Tevfik Dorak, ed. Taylor \& Francis, New York.

2. Antoniou, P. P., Markakis, E. A., Tjamos, S. E., Paplomatas, E. J., and Tjamos, E. C. 2008. Novel methodologies in screening and selecting olive varieties and root-stocks for resistance to Verticillium dahliae. Eur. J. Plant Pathol. 110:79-85.

3. Atallah, Z. K., Bae, J., Jansky, S. H., Rouse, D. I., and Stevenson, W. R. 2007. Multiplex real-time quantitative PCR to detect and quantify Verticillium dahliae colonization in potato lines that differ in response to Verticillium wilt. Phytopathology 97:865-872.

4. Beckman, C. H., and Roberts, E. M. 1995. On the nature and genetic bases for resistance and tolerance for fungal wilt diseases of plants. Adv. Bot. Res. 21:36-77.

5. Bejarano-Alcázar, J., Blanco-López, M. A., Melero-Vara, J. M., and Jiménez-Díaz, R. M. 1996. Etiology, importance, and distribution of
Verticillium wilt of cotton in southern Spain. Plant Dis. 80:1233-1238.

6. Bilodeau, G. J., Koike, S. T., Uribe, P., and Martin, F. N. 2012. Development of an assay for rapid detection and quantification of Verticillium dahliae in soil. Phytopathology 102:331-343.

7. Carder, J. H., Morton, A., Tabrett, A. M., and Barbara, D. J. 1994. Detection and differentiation by PCR of subspecific groups within two Verticillium species causing vascular wilts in herbaceous hosts. Pages 91107 in: Modern Assays for Plant Pathogenic Fungi: Identification, Detection and Quantification. A. Schots, F. M. Dewey, and R. Oliver, eds. CAB International, Wallingford, UK.

8. Chen, P., Lee, B., and Robb, J. 2004. Tolerance to a non-host isolate of Verticillium dahliae in tomato. Physiol. Mol. Plant Pathol. 64:283-291.

9. Colella, C., Miacola, C., Amenduni, M., D'Amico, M., Bubici, G., and Cirulli, M. 2008. Sources of Verticillium wilt resistance in wild olive germplasm from the Mediterranean region. Plant Pathol. 57:533-539.

10. Collado-Romero, M., Mercado-Blanco, J., Olivares-García, C., and Jiménez-Díaz, R. M. 2008. Phylogenetic analysis of Verticillium dahliae vegetative compatibility groups. Phytopathology 98:1019-1028.

11. Collado-Romero, M., Mercado-Blanco, J., Olivares-García, C., ValverdeCorredor, A., and Jiménez-Díaz, R. M. 2006. Molecular variability within and among Verticillium dahliae vegetative compatibility groups determined by fluorescent amplified fragment length polymorphism and polymerase chain reaction markers. Phytopathology 96:485-495.

12. Dervis, S., Mercado-Blanco, J., Erten, L., Valverde-Corredor, A., and Pérez-Artés, E. 2010. Verticillium wilt of olive in Turkey: A survey of disease importance, pathogen diversity and susceptibility of relevant olive cultivars. Eur. J. Plant Pathol. 127:287-301.

13. Duressa, D., Rauscher, G., Koike, S. T., Mou, B., Hayes, R. J., Maruthachalam, K., Subbarao, K. V., and Klosterman, S. J. 2012. A realtime PCR assay for detection and quantification of Verticillium dahliae in spinach seed. Phytopathology 102:443-451.

14. Erten, L., and Yildiz, M. 2011. Screening for resistance of Turkish olive cultivars and clonal rootstocks to Verticillium wilt. Phytoparasitica 39:8392.

15. Eynck, C., Koopmann, B., Grunewaldt-Stoecker, G., Karlovsky, P., and von Tiedemann, A. 2007. Differential interactions of Verticillium longisporum and Verticillium dahliae with Brassica napus detected with molecular and histological techniques. Eur. J. Plant Pathol. 118:259-274.

16. Gao, H., Beckman, C.H., and Mueller, W. C. 1995. The rate of vascular colonization as a measure of the genotypic interaction between various cultivars of tomato and various formae or races of Fusarium oxysporum. Physiol. Mol. Plant Pathol. 46:29-43.

17. Gayoso, C., Martínez de Ilárduya, O., Pomar, F., and Merino, F. 2007. Assessment of real-time PCR as a method to determine the presence of Verticillium dahliae in different Solanaceae cultivars. Eur. J. Plant Pathol. 118:199-209.

18. Heale, J. B., and Karapapa, V. K. 1999. The Verticillium threat to Canada's major oilseed crop: Canola. Can. J. Plant Pathol. 21:1-7.

19. Heinz, R., Lee, S. W., Saparno, A., Nazar, R. N., and Robb, J. 1998. Cyclical systemic colonization in Verticillium-infected tomato. Physiol. Mol. Plant Pathol. 52:385-396.

20. Higuchi, R., Fockler, C., Dollinger, G., and Watson, R. 1993. Kinetic PCR analysis: Real time monitoring of DNA amplification reactions. Biotechnology 11:1026-1030.

21. Hoagland, D. R., and Arnon, D. I. 1950. The water culture method for growing plants without soil. Calif. Agric. Exp. Stn. Circ. No. 347.

22. Hu, X., Nazar, R. N., and Robb, J. 1993. Quantification of Verticillium biomass in wilt disease development. Physiol. Mol. Plant Pathol. 42:2336.

23. Inderbitzin, P., Bostock, R. M., Davis, R. M., Usami, T., Platt, H. W., and Subbarao, K. V. 2011. Phylogenetics and taxonomy of the fungal vascular wilt pathogen Verticillium, with the descriptions of five new species. PLoS ONE 6:e28341.

24. Jiménez-Díaz, R. M., Bubici, G., Jiménez-Gasco, M. M., Antoniou, P. P., and Tjamos, E. C. 2012. Verticillium wilt, a major threat to olive production: Current status and future prospects for its management. Plant Dis. 96:304-329.

25. Jiménez-Díaz, R. M., Mercado-Blanco, J., Olivares-García, C., ColladoRomero, M., Bejarano-Alcázar, J., Rodríguez-Jurado, D., Giménez-Jaime, A., García-Jiménez, J., and Armengol, J. 2006. Genetic and virulence diversity in Verticillium dahliae populations infecting artichoke in eastern-central Spain. Phytopathology 96:288-298.

26. Karapapa, V. K., Bainbridge, B. W., and Heale, J. B. 1997. Morphological and molecular characterization of Verticillium longisporum comb. nov., pathogenic to oilseed rape. Mycol. Res. 101:1281-1294.

27. Klosterman, S. J. 2012 Real-time PCR for the quantification of fungi in planta. Pages 121-131 in: Methods in Molecular Biology, Vol. 835, Plant Fungal Pathogens: Methods and Protocols. M. D. Bolton and B. P. H. J. Thomma, eds. Springer-Verlag, Berlin.

28. Korolev, N., Katan, J., and Katan, T. 2000. Vegetative compatibility 
groups of Verticillium dahliae in Israel: Their distribution and association with pathogenicity. Phytopathology 90:529-536.

29. Korolev, N., Pérez-Artés, E., Bejarano-Alcázar, J., Rodríguez-Jurado, D., Katan, J., Katan, T., and Jiménez-Díaz, R. M. 2001. Comparative study of genetic diversity and pathogenicity among populations of Verticillium dahliae from cotton in Spain and Israel. Eur. J. Plant Pathol. 107:443-456.

30. Landa, B. B., Montes-Borrego, M., Muñoz-Ledesma, F. J., and JiménezDíaz, R. M. 2007. Phylogenetic analysis of downy mildew pathogens of opium poppy and PCR-based in planta and seed detection of Peronospora arborescens. Phytopathology 97:1380-1390.

31. Lievens, B., Brouwer, M., Vanachter, A. C. R. C., Cammue, B. P. A., and Thomma, B. P. H. J. 2006. Real-time PCR for detection and quantification of fungal and oomycete tomato pathogens in plant and soil samples. Plant Sci. 171:155-165.

32. López-Escudero, F. J., Blanco-López, M. A., del Río, R. C., and Caballero-Reig, J. M. 2007. Response of olive cultivars to stem puncture inoculation with a defoliating pathotype of Verticillium dahliae. HortScience 42:294-298.

33. López-Escudero, F. J., del Río, C., Caballero, J. M., and Blanco-López, M. A. 2004. Evaluation of olive cultivars for resistance to Verticillium dahliae. Eur. J. Plant Pathol. 110:79-85.

34. López-Escudero, F. J., and Mercado-Blanco, J. 2011. Verticillium wilt of olive: A case study to implement an integrated strategy to control a soilborne pathogen. Plant Soil 344:1-50.

35. Markakis, E. A., Tjamos, S. E., Antoniou, P. P., Paplomatas, E. J., and Tjamos, E. C. 2009. Symptom development, pathogen isolation and realtime QPCR quantification as factors for evaluating the resistance of olive cultivars to Verticillium pathotypes. Eur. J. Plant Pathol. 124:603-611.

36. Martos-Moreno, C., López-Escudero, F. J., and Blanco López, M. A. 2006. Resistance of olive cultivars to the defoliating pathotype of Verticillium dahliae. HortScience 41:1313-1316.

37. Mercado-Blanco, J., Collado-Romero, M., Parrilla-Araujo, S., RodríguezJurado, D., and Jiménez-Díaz, R. M. 2003. Quantitative monitoring of colonization of olive genotypes by Verticillium dahliae pathotypes with real-time polymerase chain reaction. Physiol. Mol. Plant Pathol. 63:91105.

38. Mercado-Blanco, J., Rodríguez-Jurado, D., Parrilla-Araujo, S., and Jiménez-Díaz, R. M. 2003. Simultaneous detection of the defoliating and nondefoliating Verticillium dahliae pathotypes in infected olive plants by duplex, nested polymerase chain reaction. Plant Dis. 87:1487-1494.

39. Mercado-Blanco, J., Rodríguez-Jurado, D., Pérez-Artés, E., and JiménezDíaz, R. M. 2002. Detection of the defoliating pathotype of Verticillium dahliae in infected olive plants by nested PCR. Eur. J. Plant Pathol. 108:1-13.

40. Montes-Borrego, M., Muñoz-Ledesma, F. J., Jiménez-Díaz, R. M., and Landa, B. B. 2011. Real-time PCR quantification of Peronospora arborescens, the opium poppy downy mildew pathogen, in seed stocks and symptomless infected plants. Plant Dis. 95:143-152.

41. Navas-Cortés, J. A., Landa, B. B., Mercado-Blanco, J., Trapero-Casas, J. L., Rodríguez-Jurado, D., and Jiménez-Díaz, R. M. 2008. Spatiotemporal analysis of spread of Verticillium dahliae pathotypes within a high tree density olive orchard in southern Spain. Phytopathology 98:167-180.

42. Nigro, F., Schena, L., and Gallone, P. 2002. Diagnosi in tempo reale della verticilliosi dell'olivo mediante Scorpion-PCR. Pages 454-461 in: Proceeding Convegno Internazionale di Olivicoltura, Spoleto, Italy. (In Italian)

43. Paris, R., and Lamattina, L. 2002. Increased ratio of mitochondrial rDNA to cytoplasmic rDNA during zoosporic and germinating cyst stages of the life cycle of Phytophthora infestans (Mont.) de Bary. Can. J. Microbiol. 48:268-274

44. Pérez-Artés, E., García-Pedrajas, M. D., Bejarano-Alcázar, J., and Jiménez-Díaz, R. M. 2000. Differentiation of cotton-defoliating and nondefoliating pathotypes of Verticillium dahliae by RAPD and specific PCR analyses. Eur. J. Plant Pathol. 106:507-517.

45. Pramateftaki, P. V., Antoniou, P. P., and Typas, M. A. 2000. The complete DNA sequence of the nuclear ribosomal RNA gene complex of Verticillium dahliae: Intraspecific heterogeneity within the intergenic spacer region. Fungal Genet. Biol. 29:19-27.

46. Schiliró, E., Ferrara, M., Nigro, F., and Mercado-Blanco, J. 2012. Genetic responses induced in olive roots upon colonization by the biocontrol endophytic bacterium Pseudomonas fluorescens PICF7. PLoS One 7:e48646

47. Smith, H. C. 1965. The morphology of Verticillium albo-atrum, V. dahliae and V. tricorpus. N. Z. J. Agric. Res. 8:540-478.

48. Steventon, L. A., Fahleson, J., Hu, Q., and Dixelius, C. 2002. Identification of the causal agent of Verticillium wilt of winter oilseed rape in Sweden, V. longisporum. Mycol. Res. 106:570-578.

49. Talboys, P. W. 1960. A culture medium aiding the identification of Verticillium albo-atrum and V. dahliae. Plant Pathol. 9:57-58.

50. Tjamos, E. C. 1993. Prospects and strategies in controlling Verticillium wilt of olive. Bull. OEPP/EPPO Bull. 23:505-512.

51. Tjamos, E. C., and Jiménez Díaz, R. M. 1998. Management of disease. Pages 55-57 in: A Compendium of Verticillium Wilt in Tree Species. J. A. Hiemstra and D. C. Harris, eds. Posen and Looijen, Wageningen, The Netherlands.

52. Vaerman, J. L., Sausssoy, P., and Ingargiola, I. 2004. Evaluation of realtime PCR data. J. Biol. Regul. Homeost. Agents 18:212-214.

53. Veronese, P., Narasimhan, M. L., Stevenson, R. A., Zhu, J. K., Weller, S C., Subbarao, K. V., and Bressan, R. A. 2003. Identification of a locus controlling Verticillium disease symptom response in Arabidopsis thaliana. Plant J. 35:574-587.

54. Zare, R., Gams, W., Starink-Willemse, M., and Summerbell, R. C. 2007. Gibellulopsis, a suitable genus for Verticillium nigrescens, and Musicillium, a new genus for V. theobromae. Nova Hedwigia 85:463-489. 